\title{
JOURNAL.RU
}

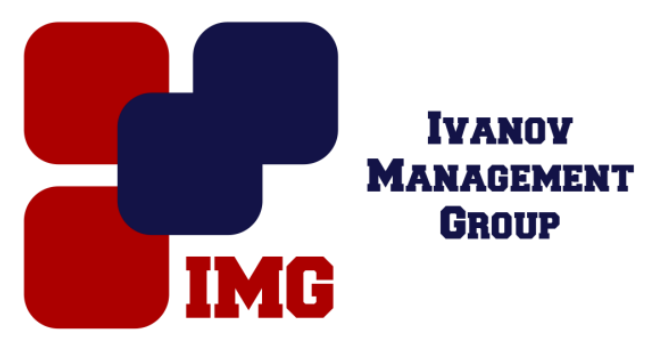

Евтых C.A.

Кубанский государственный университет физической культуры, спорта и туризма Краснодар, Россия

doi: $10.18411 / 1 \mathrm{j}-31-07-2017-07$

idsp 000001:1j-31-07-2017-07

\section{Психология здоровья как одна из ведущих дисциплин в подготовке бакалавров физической культуры по профилю физкультурно- оздоровительные технологии}

\section{Аннотация}

В статье рассматривается необходимость включения в учебный план вариативной части программы подготовки бакалавров по профилю физкультурно-оздоровительные технологии дисциплину «Психология здоровья в физкультурно-оздоровительной деятельности», основной целью которой является формирование знаний, умений и навыков по определению психоэмоционального состояния занимающихся и особенностей их коррекции средствами оздоровительной физической культуры и фитнеса. Определены модули и темы изучаемой дисциплины, а также выявлены формируемые компетенции.

Ключевые слова: бакалавр, физкультурно-оздоровительные технологии, психоэмоциональное состояние, здоровье, оздоровительная физическая культура, фитнес, психология здоровья в физкультурно-оздоровительной деятельности, компетенция

В настоящее время содержание образовательной деятельности вуза по направлению подготовки 49.03.01 Физическая культура (уровень бакалавриата) определяется федеральным государственным образовательным стандартом высшего образования (Зарегистрировано в Минюсте России 25.08.2014 N 33796). Данный стандарт представляет собой совокупность требований, 
обязательных при реализации основных профессиональных образовательных программ высшего образования - программ бакалавриата.

В стандарте прописано, что структура программы бакалавриата включает обязательную часть (базовую) и часть, формируемую участниками образовательных отношений (вариативную). Дисциплины, относящиеся к базовой части программы, являются обязательными для освоения обучающимися вне зависимости от профиля программы бакалавриата, которую он осваивает. Дисциплины, относящиеся к вариативной части программы определяют направленность программы подготовки и выбираются обучающимися из перечня предлагаемых профилируемой кафедрой [3, с. 7,8].

Кафедра физкультурно-оздоровительных технологий выпускает студентов, профессиональная деятельность которых связана с умениями и навыками формировать, сохранять и укреплять здоровье разных возрастных групп населения средствами оздоровительной физической культуры и фитнеса. В этой связи в перечень дисциплин, относящихся по выбору студента, относятся: Теоретические основы физкультурно-оздоровительной деятельности, Спортивно-оздоровительный мониторинг, Основы рекреационной и реабилитационной деятельности, Здоровый образ жизни, Рекреационная и реабилитационная деятельность различных групп населения, Тренажеры в физкультурно-оздоровительной тренировке, Программно-методическое обеспечение физкультурно-оздоровительной деятельности, Новое в физкультурно-оздоровительных технологиях. Однако, исходя из основополагающих составляющих понятия здоровья (физический, социальный, психический) вышеперечисленные дисциплины раскрывают только лишь физический его аспект, оставляя за рамками социальный и психологический. А ведь именно последние два могут повлиять на внутреннюю гармонию человека и процессы его адаптации к неблагоприятным факторам внешней среды, что приводит к нарушению гомеостаза. Это обусловлено тем, что человек являясь частью социального общества, на протяжении всей своей жизнедеятельности испытывает стресс, который может быть как положительным (эустресс), так и отрицательным (дистресс). Именно отрицательный стресс способен вызвать нарушение ряда физиологических и психологических функций субъекта, который выражается в снижении работоспособности, сопровождаемое чувством слабосилия, расстройством когнитивных процессов и внимания, нарушений в моторной сфере. И в случае, если дистресс пролонгированного действия, то наступает эмоциональное выгорание, в результате которого происходит 
исчерпывание ресурсов индивидуума без возможности их адекватного восстановления [1, с. $105 ; 2$, с. 9]. Поэтому психологические факторы не менее важны в определении состояния здоровья либо болезни человека [7, с. 78].

Этому свидетельствуют и данные экспертов ВОЗ, которые отмечают возрастающее значение психических факторов в появлении различных соматических болезней (не мене 30\%). В этом случае люди испытывают психогенные боли, возникающие без видимых органических дисфункций. Особое значение придается механизму их возникновения, который является результатом изменений функционального состояния нервной системы под воздействием стрессогенных факторов, которые путем влияния на нервную систему изменяют состояние и функции различных органов и систем. Следует отметить, что под воздействием стресса неизбежно возникает усиленное сокращение мышц, изменяется тонус сосудов, ритм сердечной деятельности, дыхания, желудочно-кишечного тракта. Такие нарушения функций организма, как правило, возникают по причине сокращения различных мышечных групп, вызванных реакцией избегания (основная нервно-мышечная реакция на стресс) и становятся привычными. К примеру, человек, испытывающий не проходящее чувство тревоги, развивает у себя сутулость, так как это чувство вызывает сокращение мышц плечевого пояса. По степени опускания плеч и выраженности сокращения мышц шеи следует судить о силе и длительности симптомов тревоги и беспокойства у человека». [7, с. 84]. Эти нарушения функций не являются заболеваниями, типичными для общепринятой медицины, отмечает Т.Ханна (2014), и их следует рассматривать в качестве болезней адаптации [7, с. 86]. А, согласно Никифорову Г.С. (2006), эти люди, нуждаются лишь в определенной коррекции эмоционального состояния, нежели в медикаментозном лечении [4, с. 18].

Таким образом, возникает необходимость рассмотреть вышеперечисленные особенности в работе бакалавров и магистров, что позволит целостно оценивать различные нарушения, возникающие в теле человека и тем самым, комплексно их разрешать. При этом в подготовке кадров уделять внимание формированию таких умений как:

- определять психоэмоциональное состояние занимающихся и подбирать соответствующие средства оздоровительной физической культуры и фитнеса для их коррекции.

- формировать способности у занимающихся оздоровительной физической культурой и фитнесом приспосабливаться к стрессам, в 
том числе при помощи разумного использования соматических упражнений;

- подбирать упражнения, воздействующие на целостную личность в аспекте гармоничного ее развития между такими составляющими как тело, разум и дух [5, с. 39];

Включение в учебный план вариативной части по выбору студента дисциплины «Психология здоровья в физкультурно-оздоровительной деятельности», на наш взгляд, будет способствовать формированию знаний, умений и навыков по развитию психологической устойчивости личности с помощью физических упражнений. В том числе осуществлять подбор средств физической культуры и фитнеса в целях коррекции различного рода психоэмоциональных состояний; рекомендовать не только тот вид двигательной активности, который позволит справиться личности с внутренним его состоянием, но и подобрать посильную для этого состояния физическую нагрузку.

Поэтому в рамках изучения дисциплины «Психология здоровья в физкультурно-оздоровительной деятельности» предполагается рассмотрение следующих модулей:

1. Теоретические аспекты психологии здоровья в физкультурнооздоровительной деятельности, где рассматриваются факторы, влияющие на физическое, социальное и психологическое здоровье; стресс физиологический и психологический и его влияние на организм; взаимосвязь психики и тела, причины возникновения психосоматических заболеваний.

2. Практические аспекты психологии здоровья в физкультурнооздоровительной деятельности, где рассматривается оценка психологического здоровья и психоэмоционального состояния человека; средства оздоровительной физической культуры и фитнеса, направленные на коррекцию психоэмоционального состояния; особенности составления программы тренировок в зависимости от типа темперамента и психоэмоционального состояния.

3. Психология здоровья профессиональной деятельности специалиста физкультурно-оздоровительных технологий, рассматривающая вопросы эмоционального выгорания специалиста, его коппингстратегии и методы саморегуляции. 
Планируемым результатом обучения является формирование следующих компетенций:

- способность использовать методы и средства физической культуры для обеспечения полноценной социальной и профессиональной деятельности;

- способность определять анатомо-морфологические, физиологические, биохимические, биомеханические, психологические особенности физкультурно-спортивной деятельности и характер ее влияния на организм человека с учетом пола и возраста;

- способность использовать накопленные в области физической культуры и спорта духовные ценности, полученные знания об особенностях личности обучающихся для воспитания патриотизма, профилактики девиантного поведения, формирования здорового образа жизни, потребности в регулярных занятиях физической культурой;

- способность осуществлять пропаганду и обучение навыкам здорового образа жизни;

- способность реализовывать программы оздоровительной тренировки для различного контингента обучающихся, включающие в себя технологии управления массой тела, рационального питания и регуляции психического состояния [3, с. 4,5,6].

В заключении следует отметить, что включение дисциплины «Психология здоровья в физкультурно-оздоровительной деятельности» позволит выйти на новый уровень в подготовке кадров в области физкультурно-оздоровительных технологий, владеющих не только средствами оздоровительной физической культуры и фитнеса, но и способных применять эти средства в борьбе с болезнями современной цивилизации. 
1. Водопьянова Н., Старченкова Е. Синдром выгорания: диагностика и профилактика / Н. Водопьянова, Е. Старченкова. - Изд. 2-е, доп. - СПб, 2008. - 258 с.

2. Водопьянова Н.Е. Психодиагностика стресса / Н.Е. Водопьянова. - СПб, 2009. - 251 с.

3. Приказ Минобрнауки России «Об утверждении федерального государственного образовательного стандарта высшего образования по направлению подготовки 49.03.01 Физическая культура (уровень бакалавриата)» [Электронный ресурс]. КонсультантПлюс, 2014. - Режим доступа: www.consultant.ru, свободный. - Загл. с экрана.

4. Психология здоровья: учебник для вузов / Под.ред. Г.С. Никифорова. - СПб.: Питер, 2006. -607 c.

5. Рамос Д.Ж. Душа тела. Юнгианский подход к психосоматике / Д.Ж. Рамос. - М.: «Добросвет», 2016. - 192 с.

6. Стресс, выгорание, совладание в современном контексте / Под. ред. А. Л. Журавлева, Е. А. Сергиенко. - М.: Изд-во Институт психологии РАН, 2011. - 512 с.

7. Ханна Т. Искусство не стареть / Т.Ханна. - Питер, 2014. - 224 с. 